\title{
Formation Mechanism and Reduction Technology of Mining-Induced Fissures in Shallow Thick Coal Seam Mining
}

\author{
Jianwei Li and Changyou Liu \\ School of Mines, State Key Laboratory of Coal Resources and Safe Mining, China University of Mining \& Technology, Xuzhou, China \\ Correspondence should be addressed to Changyou Liu; 18795426108@163.com
}

Received 6 January 2017; Accepted 24 April 2017; Published 25 May 2017

Academic Editor: Salvatore Russo

Copyright ( 2017 Jianwei Li and Changyou Liu. This is an open access article distributed under the Creative Commons Attribution License, which permits unrestricted use, distribution, and reproduction in any medium, provided the original work is properly cited.

\begin{abstract}
Surface mining-induced fissures formed in shallow coal seam mining have serious impact on safety mining and water resources protection. This paper proposes a novel approach to study the formation mechanism and dynamic development of surface mininginduced fissures in shallow coal seam mining. This approach combines field tests, theoretical analysis, and numerical simulations based on the geological condition of shallow coal seam mining in Chuancao Gedan Coal Mine. Two typical surface mininginduced fissures, step-type fissures and collapse-type fissures, are generated in shallow coal seam mining. The fissures with large vertical throw or horizontal opening severely impact water resource protection and surface ecological environment. Surface mininginduced fissures are generated periodically and changed dynamically with the advancing of working face. The vertical throw and horizontal opening of surface fissures are changed dynamically with the movement of loading key strata. The movement forms of loading key strata determine the morphological development of surface fissures. Downward sliding movement of broken rocks causes step-type fissures, while downward rotation movement leads to collapse-type fissures. The degree of the downward sliding and rotation of broken rocks determines the vertical throw and horizontal opening of surface fissures. This paper proposes mining technologies to reduce damaging ground fissures in shallow coal seam mining and analyzes their control effects.
\end{abstract}

\section{Introduction}

With coal exploitation focus transferring to the Western China, more and more attention is paid to safety mining $[1,2]$. Mining area in Western China generally has characteristics of shallow burial depth, large coal reserves, and fragile ecological environment. Underground mining leads to large number of mining-induced fissures, resulting in ecological and environmental disasters such as land deterioration and water resources deterioration [3-5]. According to the geological condition of shallow coal seam, relevant scholars have carried out researches on mining pressure and strata control, mining subsidence and prevention technology, and water-preserved mining technology. Huang et al. established mechanical structure models of "short voussoir beam" and "step beam" of main roof, providing the basic method of supporting design for shallow coal seam working face [6]. Huang put forward the shallow seam definition for strata control by use of three key index, the key strata, the thickness ratio of rock to soft overburden, and the depth of coal seams [7]. Xing et al. and Xu et al. classified key strata structures in shallow coal seams and analyzed their structural stability $[8$, 9]. Related scholars used field tests, theoretical analysis, and numerical simulations to study overlying strata movement, mining subsidence, surface mining-induced fissures, and so on, providing principle for supporting design, subsidence trough reclamation, and ecological restoration in the mining area of shallow coal seam [10-14]. Zhang et al., Booth and Bertsch, and $\mathrm{Ma}$ et al. carried out researches on mininginduced fissures of overlying strata from the perspectives of the structure characteristics of key strata and water-resisting key strata, providing water-preserved mining technologies in shallow buried coal seam [15-17]. Large number of surface mining-induced fissures will be generated and have serious impact on surface ecological environment in shallow coal seam mining $[18,19]$. There are less related researches on dynamic development of surface mining-induced fissures, correlation between overlying strata movement and surface 

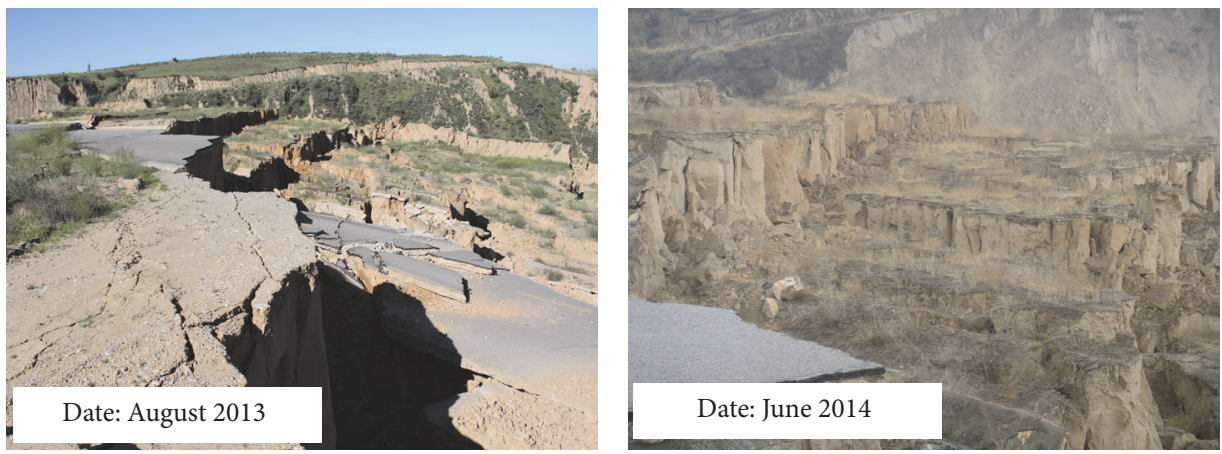

(a) Step-type fissures
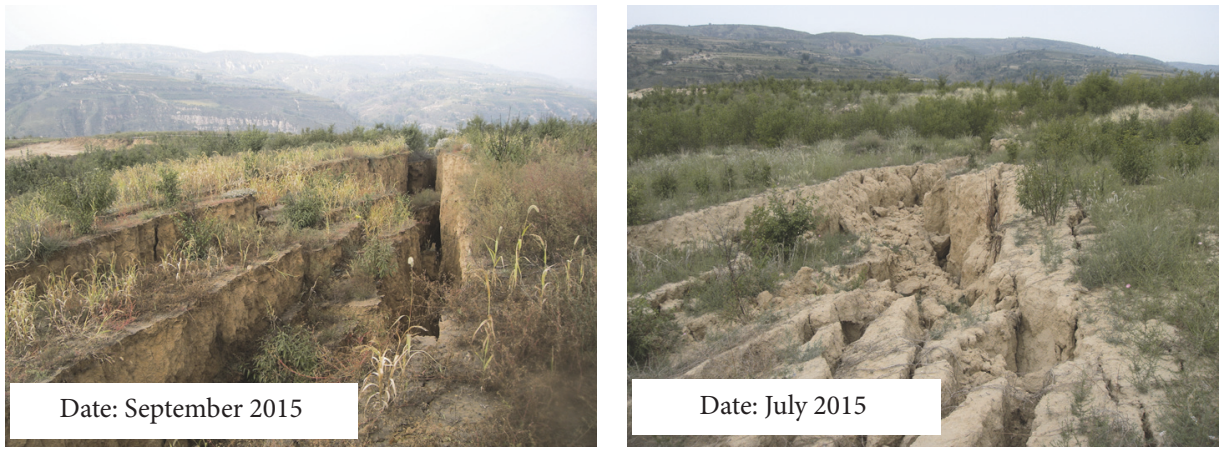

(b) Collapse-type fissures

FIgURE 1: Morphological development of damaging surface fissures and their impact on vegetation.

fissures development, formation mechanism, and reduction technologies of mining-induced fissures in shallow coal seam mining.

In this article, formation mechanism and reduction technology of mining-induced fissures in shallow coal seam mining are studied based on the geological conditions of Chuancao Gedan Coal Mine.

\section{Morphological Development of Surface Fissures in Shallow Coal Seam Mining and Their Impact on the Ecological Environment}

Surface mining-induced fissures are periodically generated with the advancing of working face based on in situ observations. These fissures cause cutting damage of surface loess layer, resulting in ecological and environmental disasters such as land deterioration and water resources deterioration. Some fissures easily cause air, water, and sand entering into working face, which has serious impact on safety mining $[6,18]$.

Two surface typical mining-induced fissures, step-type fissures and collapse-type fissures, are generated (see Figures 1 and 2). The vertical throw and horizontal opening of different surface fissures have great differences. The fissures causing great damage to ecological environment have large vertical throw or horizontal opening. The land surface vegetation cover was observed for a period of time after formation of damaging surface fissures (see Figure 1).

The results show that damaging surface fissures have serious impact on water resources protection, resulting in significant reduction of vegetation species and quality, which causes serious damage to the fragile ecological environment. Collapse-type fissures with large value of horizontal opening are prone to cause air leakage, water inrush, and sand inrush in working face, which has serious impact on safety mining

It has been accepted that ground fissures are generated in cases where the ground movement exceeds its deformation limit (Qian and Zhao, 1987; Qian et al. 1994). Figure 3 shows the horizontal and vertical displacements of two adjacent points on the ground surface after mining.

Taking Point 4 and Point 5 in Figure 4 as an example, the horizontal displacement difference $\Delta u=u_{5}-u_{4}$ refers to the horizontal opening of the fissure between these points, and the vertical displacement difference $\Delta w=w_{5}-w_{4}$ refers to the vertical throw of the fissure between these points. Additionally, the overburden of most shallow seams is loess strata or aeolian sand strata with low mechanical strength, viscosity, and shear resistance. Therefore, ground fissures are generated in the presence of slight tensile or shear stress. With a large $\Delta u$, bifurcation separation of ground fissures was observed on the weak sides, and the triangle between the two branches shifted downward, resulting in collapse grooves.

\section{Dynamic Development of Surface Fissures in Shallow Coal Seam Mining}

Based on the geological condition of Chuancao Gedan Coal Mine, this section measures and analyzes the dynamic development of step-type fissures and collapse-type fissures 


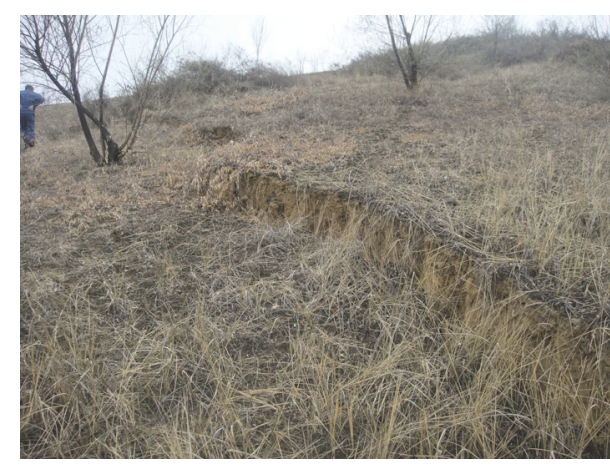

(a) Step-type fissure

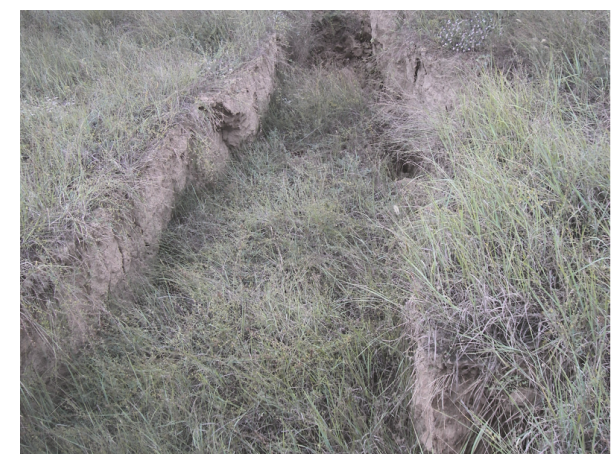

(b) Collapse-type fissure

FIGURE 2: Vegetation growth after generation of nondamaging surface fissures.

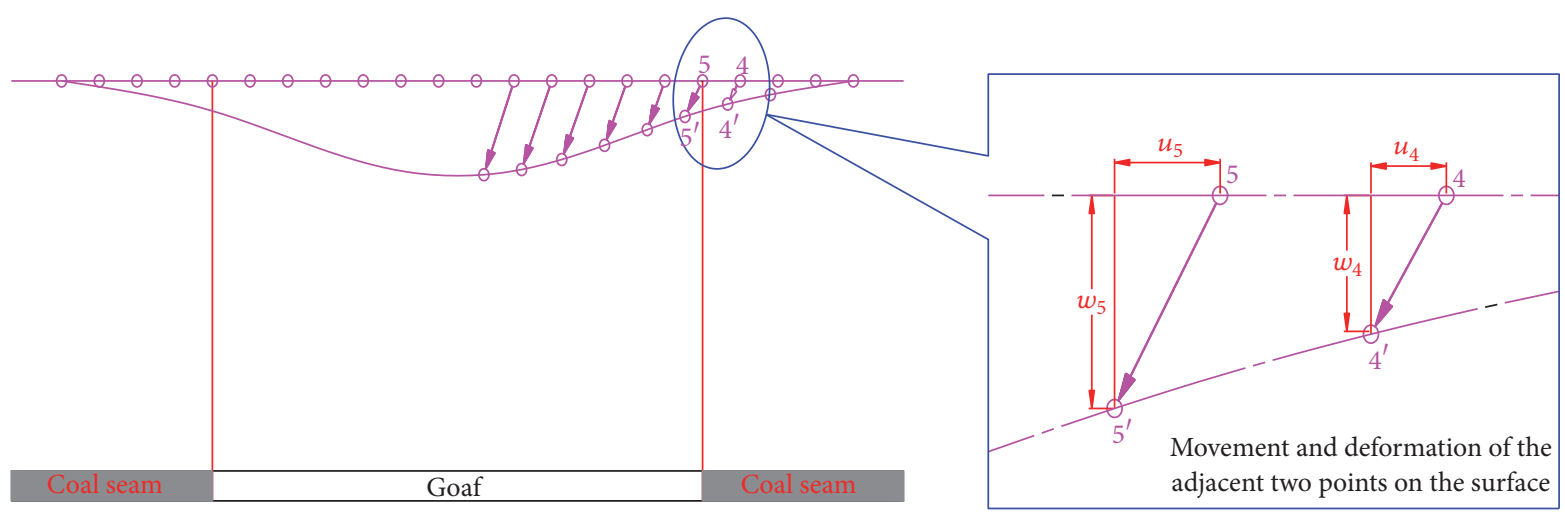

FIGURE 3: Movement of surface points after shallow coal seam mining.

as well as their correlation with periodic weighting (expression form of main roof periodic breakage on mining face) of working face. The main controlling factor influencing the formation and development of surface fissures is found.

3.1. Dynamic Development of Step-Type Fissures with the Advancing of Working Face. Working face 4104 of Chuancao Gedan Coal Mine is $1834 \mathrm{~m}$ in length and $253 \mathrm{~m}$ in width, with an average thickness of $3.5 \mathrm{~m}$ and an average buried depth of $80.7 \mathrm{~m}$. The borehole columnar section of Working face 4104 is shown in Figure 4(a).

Figure 4(b) is that surface fissures in the $130-280 \mathrm{~m}$ section of Coalface 4104 were measured on-site once the mining face had advanced to the $290 \mathrm{~m}$ position. The surface mining-induced fissures are generated periodically with the advancing of Working face 4104 . The fissures are distributed along the length direction of the working face. The morphological development of the fissures is step-type shape. The fissures distance ranged from $12.6 \mathrm{~m}$ to $19.1 \mathrm{~m}$ (average distance $=14.9 \mathrm{~m}$ ).

Through field measurement analysis, the development of surface mining-induced fissures in the middle of working face is earlier than both ends of working face. The surface fissures were measured from April 20 to April 26 in 2011. The dynamic development of vertical throw and horizontal opening of ground fissures $1 \#$ in the middle of Working face 4104 is shown in Figure 5(a).

In the middle of Working face 4104, the fissure horizontal opening fluctuates between $2 \mathrm{~mm} \sim 15 \mathrm{~mm}$; both the fissure horizontal opening and variable quantity are small. The fissure vertical throw fluctuates between $0 \mathrm{~mm} \sim 360 \mathrm{~mm}$ and increases with the advance of mining coal face. The vertical throw changes little when fissures are ahead of working face and increases sharply when fissures are located near the top of working face.

The relationship between the fissure vertical throw and support resistance of hydraulic support in the middle of Working face 4104 is shown in Figure 5(b). There is one cycle of periodic weighting in the middle of Working face 4104 during observation. Vertical throw of the surface mininginduced fissures mutated and reached maximum value of $310 \mathrm{~mm}$ after periodic weighting.

3.2. Dynamic Development of Collapse-Type Fissures with the Advancing of Working Face. Working face 6104 of Chuancao Gedan Coal Mine is $2093 \mathrm{~m}$ in length and $148 \mathrm{~m}$ in width, with an average thickness of $12.8 \mathrm{~m}$ and an average buried depth of $116.6 \mathrm{~m}$. The borehole columnar section of Working face 6104 is shown in Figure 6(a).

Figure 6(b) is that surface fissures in the $0-220 \mathrm{~m}$ section of Coalface 6104 were measured on-site once the mining face 


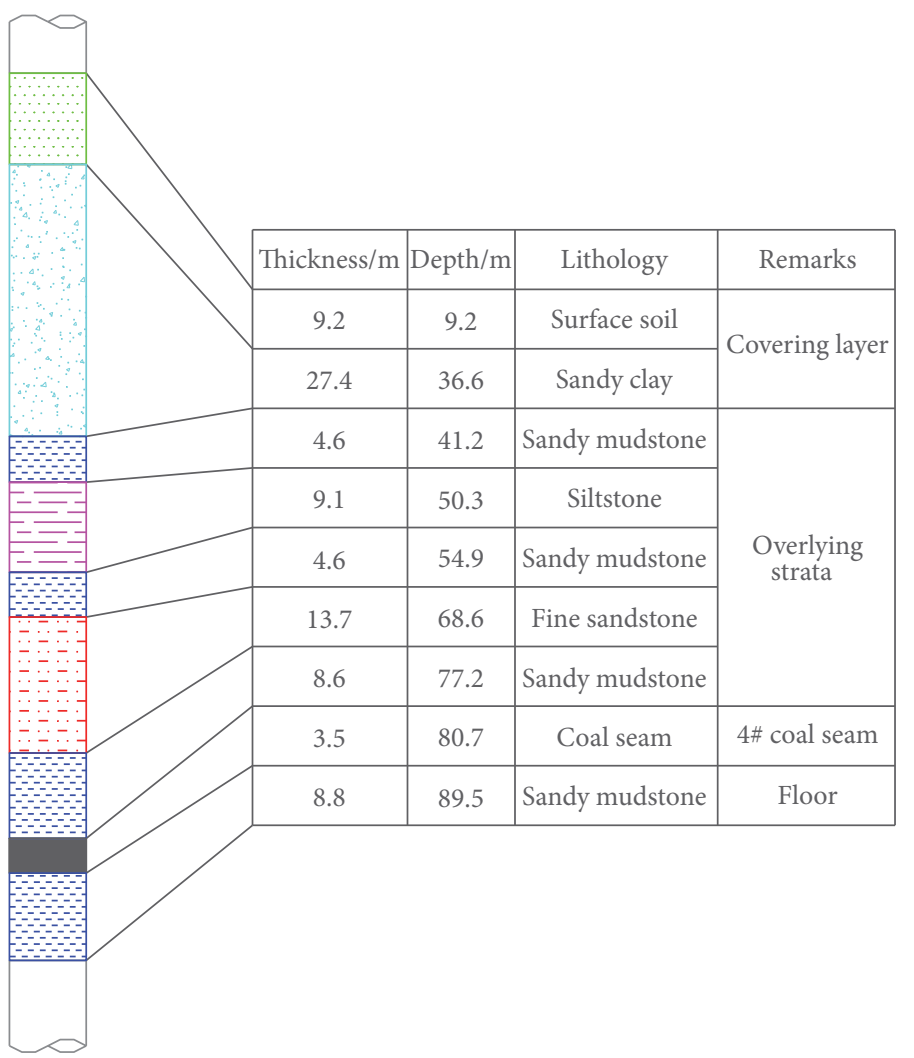

(a)

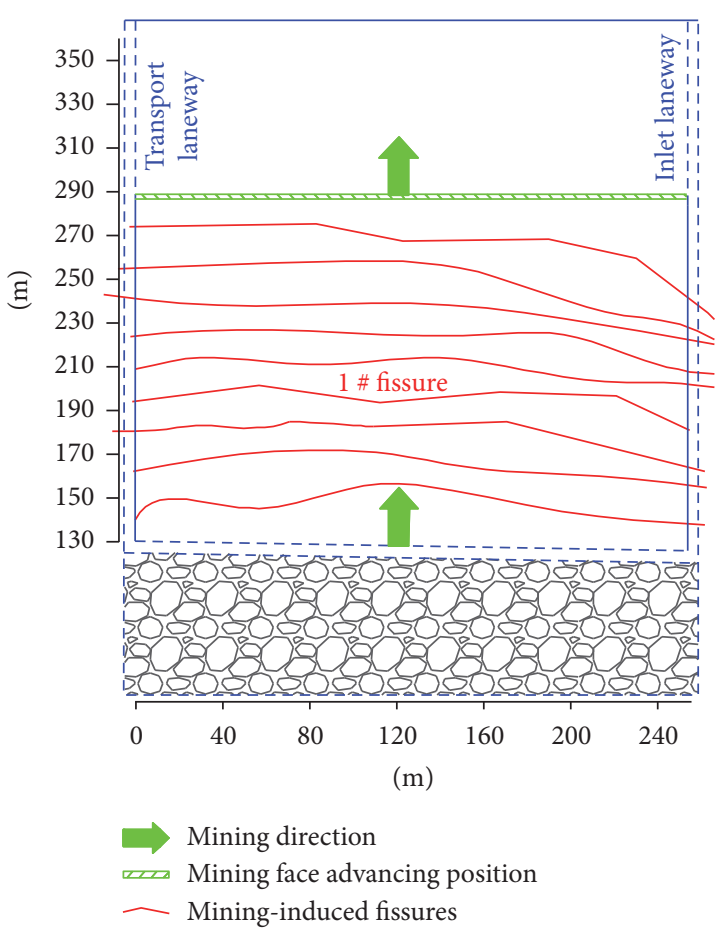

(b)

FIGURE 4: Borehole columnar section and major surface fissures of Working face 4104.

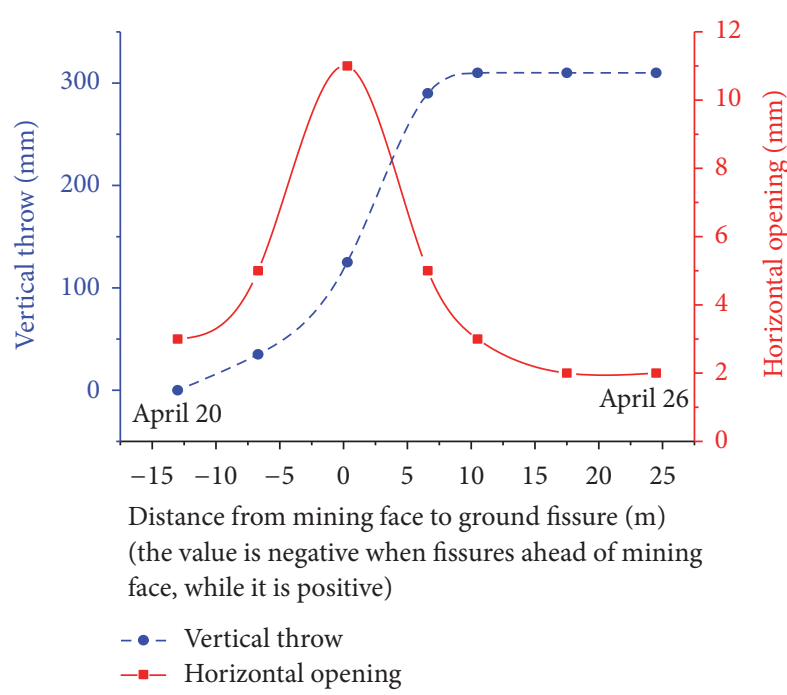

(a)

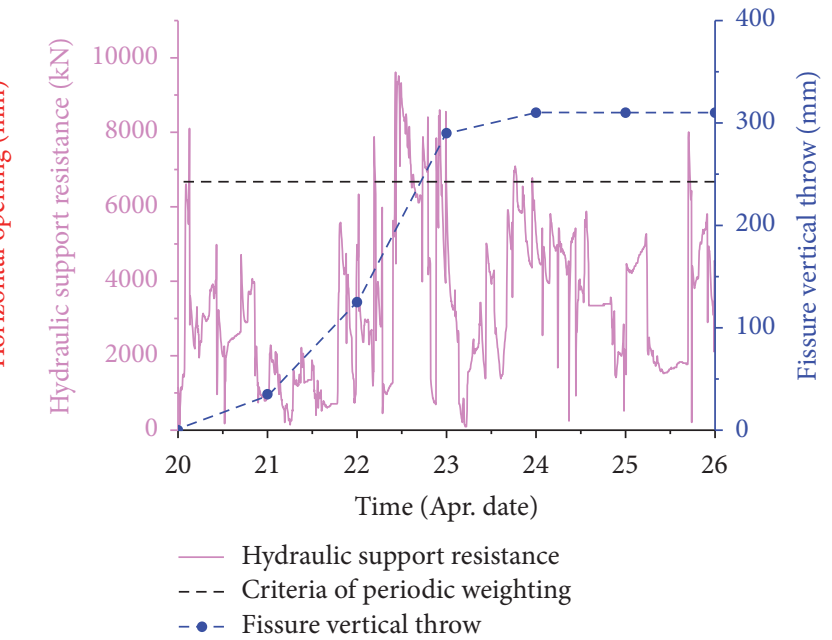

(b)

FIGURE 5: Dynamic development of mining-induced fissures in Working face 4104.

had advanced to the $230 \mathrm{~m}$ position. The fissures are also generated periodically and distributed along the length direction of the working face. The morphological development of the fissures is central-sink shape. The fissures distance ranged from $12.7 \mathrm{~m}$ to $23.8 \mathrm{~m}$ (average distance $=17.5 \mathrm{~m}$ ).

The dynamic development of vertical throw and horizontal opening of ground fissures $1 \#$ in the middle of Working face 6104 from September 15 to September 25 in 2014 is shown in Figure 7(a).

The ground fissures have large vertical throw and horizontal opening in the middle of Working face 6104 . The vertical throw and horizontal opening fluctuate between $0 \mathrm{~mm} \sim 1100 \mathrm{~mm}$. The ground fissures are collapse-type fissures. The fissure horizontal opening increases and then 


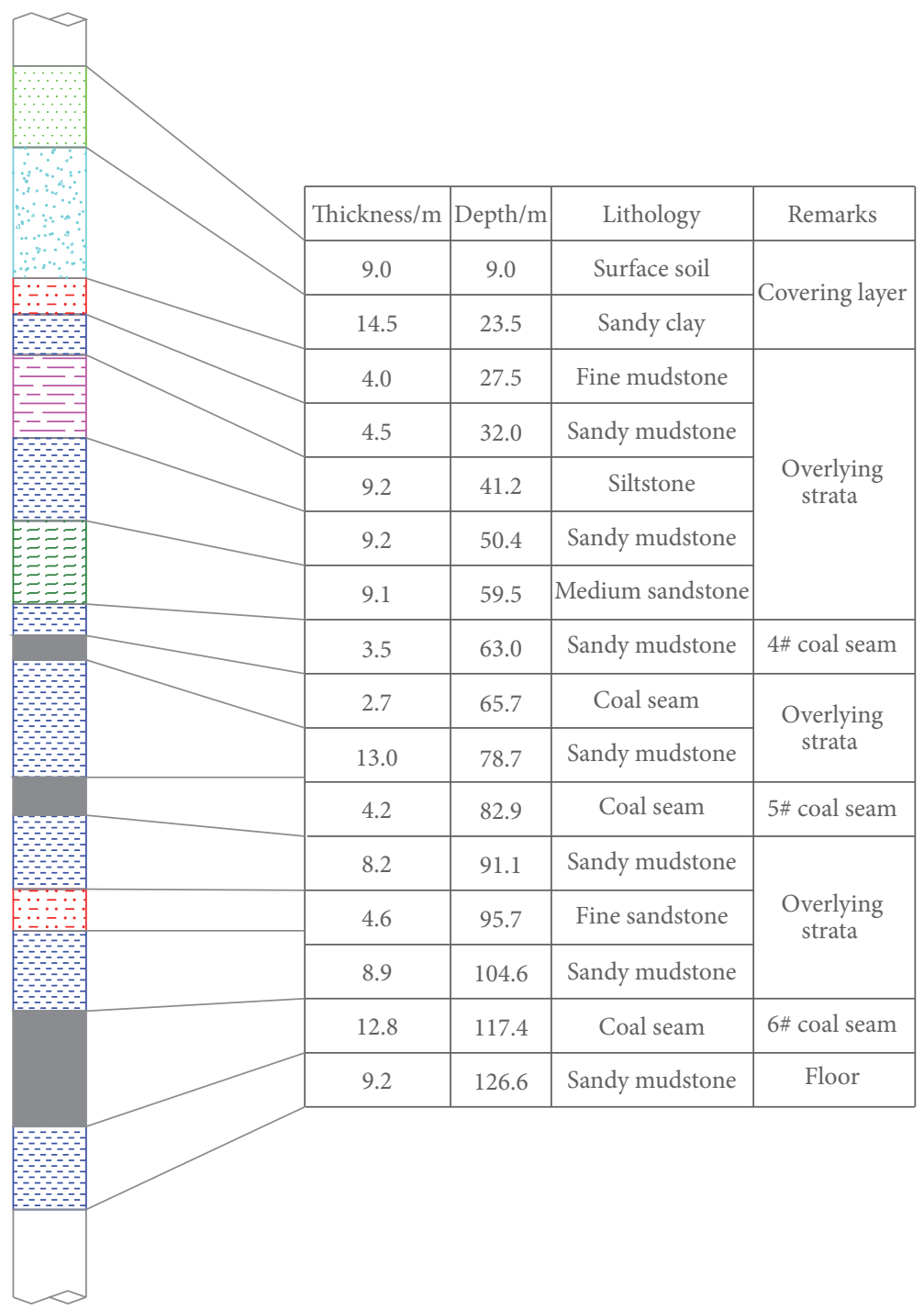

(a)

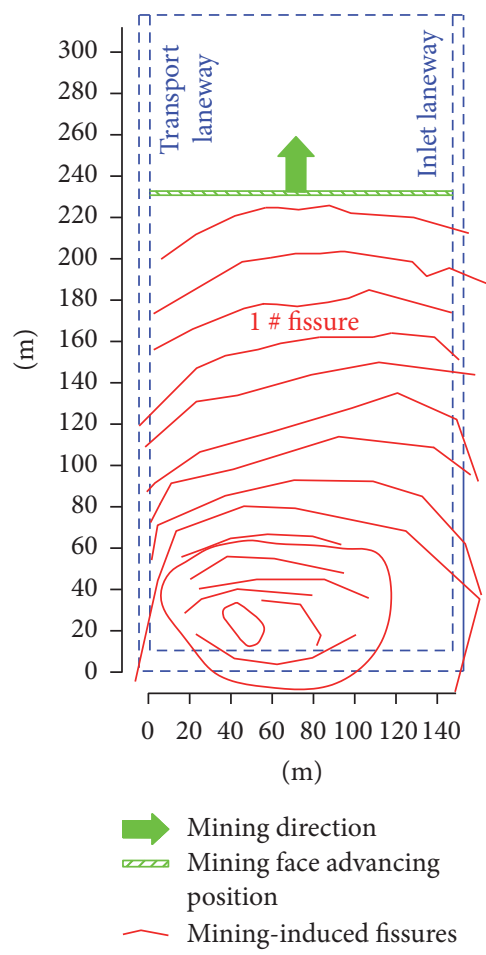

(b)

FIGURE 6: Borehole columnar section and major surface fissures of Working face 6104.

decreases with the advancing of working face. The maximum horizontal opening and vertical throw occur when the lag distance is about $10 \mathrm{~m}$. The horizontal opening decreases gradually with the increase of the lag distance between the fissure and the working face and is less than $450 \mathrm{~mm}$ when the lag distance $>30 \mathrm{~m}$. Because of the squeezing effect of the earth's surface soil, the value of the vertical throw tends to be stable after it reaches the maximum value.

The relationship between the fissure vertical throw and horizontal opening and support resistance of hydraulic support in the middle of working face is shown in Figure 7(b). There were two cycles of periodic weighting in the middle of Working face 6104 during observation. After the periodic weighting in the middle of Working face 6104, the vertical throw and horizontal opening of the surface mining-induced fissure mutated and reached maximum.
Next periodic weighting causes the dimension parameter of other ground fissures to mutate and reach maximum value.

\section{Movement Forms of Overlying Strata and Formation Mechanism of Surface Fissure in Shallow Coal Seam Mining}

Per on-site measurements, the ground fissures are generated periodically with the advancing of working face. The vertical throw and horizontal opening of surface fissures mutate with roof weighting. It indicates that there are strata controlling the upper strata to surface cover layer. The periodic fracture of this rock strata causes movement of its overlying strata and the loose layer and leads to ground surface fissures. These strata are called loading key strata $[20,21]$. The loading key 


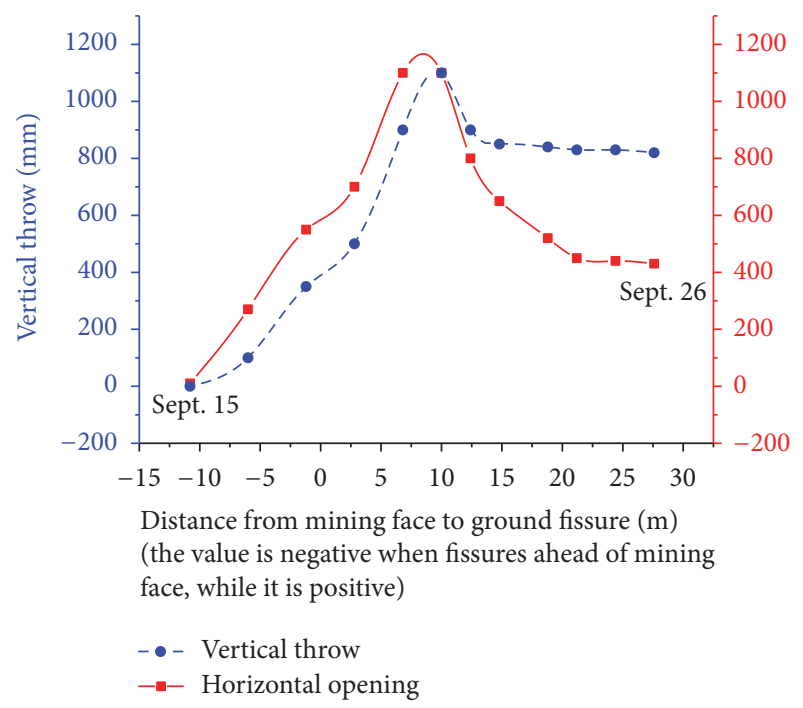

(a)

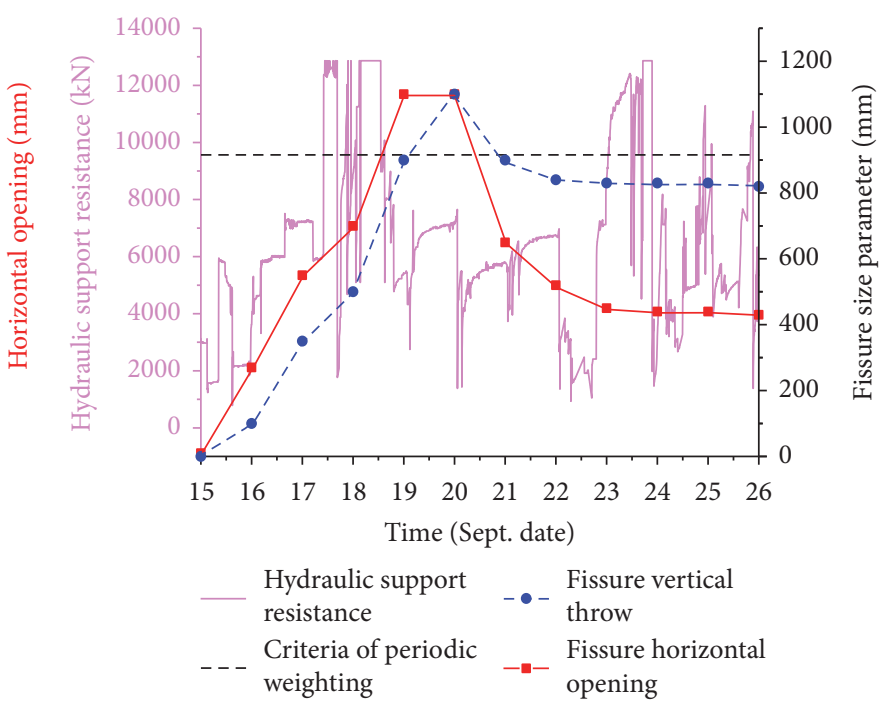

(b)

FIGURE 7: Dynamic development of mining-induced fissures in Working face 6104.

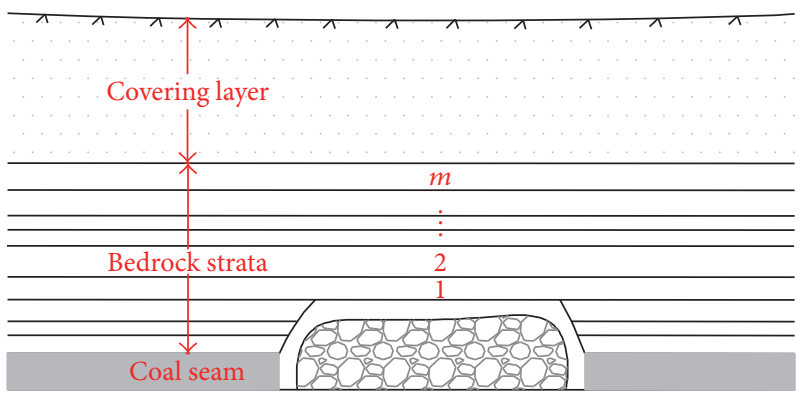

FIGURE 8: Distribution of overlying strata in shallow thick coal seam.

strata are hard and thick strata, which support the upper strata and the loose covering layer in some form of mechanical structure. Their periodic fracture directly influences roof pressure, strata movement, and mining subsidence. The movement forms of the loading key strata have a great significance for overlying strata movement and formation mechanism of ground fissures in shallow coal seam mining.

The distribution of the overlying strata in a shallow buried coal seam is shown in Figure 8. The coal seam is covered with stratum 1 to $m$. The upper layer is the loose covering layer, which is composed of soil or weak rock.

The thickness of each stratum is set to $h_{i}$, the volume force is $\gamma_{i}$, the modulus of elasticity is $E_{i}$, and $i=1,2,3, \ldots, m$. Per the theory of key strata (Qian and Zhao 1987), the loading key strata of the overlying strata in shallow coal seam mining must meet the following three conditions:

$$
\begin{aligned}
q_{n} & >q_{n-1}>\cdots>q_{1}, \\
q_{n} & =\left(q_{n}\right)_{\text {overburden }}, \\
\left(q_{n}\right)_{\text {overburden }} & >\left(q_{n}\right)_{n+1}>\cdots>\left(q_{n}\right)_{m}, \\
L_{n} & >L_{n+1}>\cdots>L_{m} .
\end{aligned}
$$

Among them,

$$
\begin{aligned}
\left(q_{n}\right)_{\text {overburden }}= & E_{n} h_{n}{ }^{3} \\
& \cdot \frac{\left(\sum_{i=n}^{i=m} \gamma_{i} h_{i}+\gamma_{\text {overburden }} h_{\text {overburden }}\right)}{\sum_{i=n}^{i=m} E_{i} h_{i}{ }^{3}}, \\
\left(q_{n}\right)_{m}= & E_{n} h_{n}{ }^{3} \cdot \frac{\sum_{i=n}^{i=m} \gamma_{i} h_{i}}{\sum_{i=n}^{i=m} E_{i} h_{i}{ }^{3}} .
\end{aligned}
$$

In the formula, $\left(q_{n}\right)_{\text {overburden }}$ is the load under the action of the bedrock and covering strata on strata $n, \mathrm{kN} / \mathrm{m}^{2} ;\left(q_{n}\right)_{m}$ is the load under the action of strata $m$ on strata $n, \mathrm{kN} / \mathrm{m}^{2}$; $q_{i}(i=1,2,3, \ldots, n)$ is the load of strata $i, \mathrm{kN} / \mathrm{m}^{2} ; L_{i}(i=$ $n, n+1, \ldots, m)$ is the caving step distance of strata $i, \mathrm{~m} ; \gamma_{i}$, $E_{i}$, and $h_{i}$ are the rock average bulk density, average elastic modulus, and thickness of rock strata of strata $i, \mathrm{kN} / \mathrm{m}^{3}$, $\mathrm{MPa}$, and $\mathrm{m}$, respectively; $\gamma_{\text {overburden }}$ and $h_{\text {overburden }}$ are the average bulk density of bedrocks and overburden as well as overburden thickness, $\mathrm{kN} / \mathrm{m}^{3}$ and $\mathrm{m}$, respectively.

Equation (1) indicates that the loading key strata are determined according to the load step and the load [7].

According to the lithology characteristics of coal and rock and their physical and mechanical parameters of Working face 4104 and 6104, combined with formula (1), the loading key strata in Working face 4104 are fine-grained sandstone strata with thickness of $13.7 \mathrm{~m}$ and the loading key strata in Working face 6104 are siltstone strata with thickness of $9.2 \mathrm{~m}$. Using 3DEC numerical simulation software $[22,23]$, the movement characteristics of overlying strata in the working face are analyzed as follows:

(1) The mining height of Working face 4104 is $3.5 \mathrm{~m}$. According to the observation results of surface fissures, the broken strata size $h \times l$ (rock thickness $\times$ broken length) of loading key strata is $14.0 \mathrm{~m} \times 15.0 \mathrm{~m}$. 


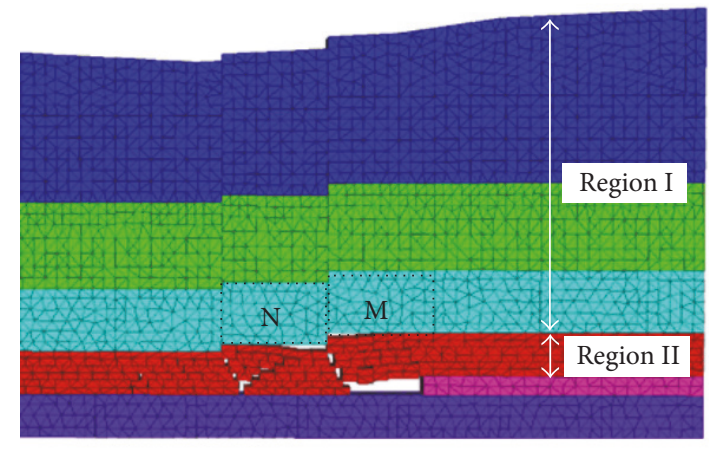

(a)

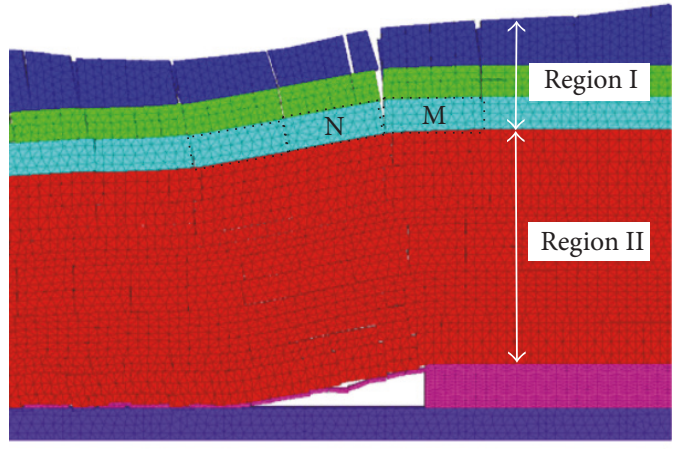

(b)

FIGURE 9: Movement form of the loading key strata and the overlying strata under supercritical extraction of Working face 4104 and Working face 6104 .

The movement of the loading key strata and the overlying strata in Working face 4104 is shown in Figure 9(a).

(2) The mining height of Working face 6104 is $12.8 \mathrm{~m}$. According to the observation results of surface fissures, the broken strata size $h \times l$ (rock thickness $\times$ broken length) of loading key strata is $9.0 \mathrm{~m} \times$ $17.0 \mathrm{~m}$. The movement of the loading key strata and the overlying strata in Working face 6104 is shown in Figure 9(b).

The fracture of loading key strata causes the movement of overlying strata and covering layer, which leads directly to surface mining-induced fissures.

Separating by loading key strata, the overburden strata in shallow coal seam mining are divided into two regions, which is shown in Figures 9(a) and 9(b). There are loading key strata, upper strata, and surface covering layer in region I. The generation and dynamic variation of mining-induced fissures are influenced by the breaking and movement of the loading key strata. There are bedrock strata (lower bedrock strata) from the immediate roof to the loading key strata in region II. The rock strata in this area are irregular or regular caved with the coal seam mining.

According to the geometrical characteristics and articulated structure of broken rocks, the loading key strata may form two kinds of structure after breaking, which are "step beam" (Figure 9(a)) and "voussoir beam" (Figure 9(b)). When the mined out space cannot be fully filled by caving strata under the loading key strata and there is free space between the caved coal gangue and loading key strata, rock block $\mathrm{N}$ and rock block $\mathrm{M}$ will form the "step beam" structure. Rock block $\mathrm{N}$ falls completely on the caved coal gangue; rock block $\mathrm{M}$ moves with the advance of the mining coal face. When the mined out space can be fully filled by caving strata under the loading key strata and there is no free space between the caved coal gangue and loading key strata, rock block $\mathrm{M}$ and rock block $\mathrm{N}$ will form the "voussoir beam" structure.

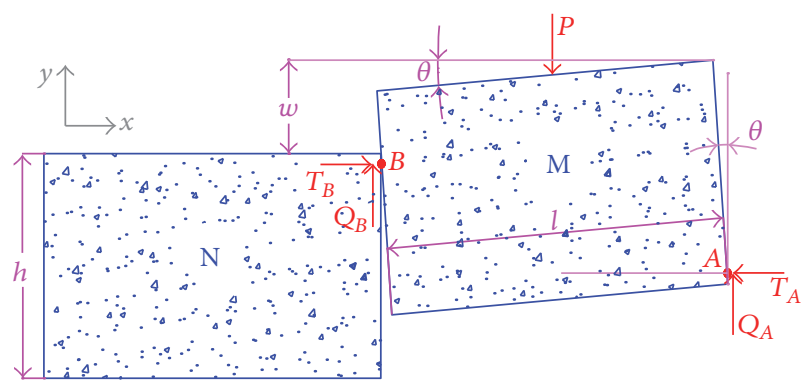

FIGURE 10: "Step beam” structure of the rock block M and rock block $\mathrm{N}$.

According to the movement of the overlying strata in Figure 9(a), the "step beam" structure of the loading key strata is shown in Figure 10. Rock block $\mathrm{M}$ and rock block $\mathrm{N}$ form the "step beam" structure. Rock block N falls completely on caved coal gangue. Rock block $M$ rotates with the advance of the mining coal face. It is supported at point $A$ (from nonbroken rock masses) and point $B$ (from rock block $\mathrm{N}$ ).

In order to analyze the movement form of the "step beam" structure, the mechanical analysis of the key block $M$ is as follows.

The mined out space cannot be fully filled by the caving strata below the loading key strata. Therefore, rock block $\mathrm{N}$ falls completely on the caved coal gangue and the subsidence amount of rock $\mathrm{N}$ is

$$
w=M-\left(K_{Z}-1\right) L
$$

In the formula, $M$ is mining height, $\mathrm{m} ; K_{Z}$ is hulking coefficient of caved rock, generally taking the value of 1.1 1.3; $L$ is thickness of bedrock strata below the loading key strata, $\mathrm{m}$.

Defining the difference value between loading key strata thickness $h$ and rock subsidence amount $w$ to be overlap thickness $h_{0}$ among the broken rocks of the loading key strata, then $h_{0}=h-w$. Defining the ratio between the overlap thickness of the broken rocks of loading key strata $h_{0}$ and the loading strata thickness $h$ to be the overlap coefficient 
$n$ among the rocks of the loading key strata, then $n$ can be expressed in the following equation:

$$
n=\frac{h_{0}}{h}=\frac{h-w}{h}
$$

where the value range of $n$ is $0 \sim 1$.

According to the geometrical contact relations of rock rotation, considering the rock extrusion plastic deformation and the stress situation during the critical instability of rock $M$, assuming the horizontal forces $T_{A}$ and $T_{B}$ are located in the boundary position of the rock extrusion plastic deformation size $a, a$ can be expressed in the following equation:

$$
a=\frac{1}{2}(h-l \sin \theta),
$$

where $h$ is the thickness of loading key strata; $l$ is the length size of breaking limit of loading key strata; $\theta$ is the rotation distortion angle of the broken rocks.

Analyzing rock $\mathrm{M}$, taking the equilibrium condition of horizontal and vertical force $Q_{A}=Q_{B}$, we can get

$$
\begin{aligned}
\sum F_{x} & =0, \\
T_{A} & =T_{B}, \\
\sum F_{y} & =0, \\
Q_{A} & =Q_{B}=\frac{P}{2} .
\end{aligned}
$$

The moment equilibrium condition at point $A$ is

$$
\begin{aligned}
& \sum M_{A}=0, \\
& Q_{B}\left[l \cos \theta+\left(h-w-\frac{3}{2} a\right) \tan \theta\right]-P \frac{l}{2} \cos \theta \\
& \quad+T_{B}(h-w-2 a)=0 .
\end{aligned}
$$

According to the upper formula, we can get the horizontal extrusion pressure of the block edge:

$$
T_{A}=T_{B}=\frac{P(h-w-(3 / 2) a) \tan \theta}{2(h-w-2 a)} .
$$

The span-thickness ratio of the broken rocks is set to be $\varepsilon$, $\varepsilon=l / h$, formula (4) and formula (5) are brought into formula (8), and we can get

$$
T_{A}=T_{B}=\frac{P(3 n-1+\varepsilon \sin \theta) \tan \theta}{4(n-1+\varepsilon \sin \theta)} .
$$

If the downward sliding movement of rock $\mathrm{M}$ at point $A$ occurs, it must meet the following condition:

$$
T_{A} \tan \varphi \geq Q_{A},
$$

where $\tan \varphi$ is the friction factor among the broken rocks, generally taking the value of 0.5 .
Bringing $Q_{A}=P / 2$ and formula (9) into formula (10), we can get the condition which should be satisfied if rock $M$ does not appear downward sliding movement:

$$
\varepsilon \geq \frac{4-4 n+3 n \tan \theta-\tan \theta}{\sin \theta(4-\tan \theta)} .
$$

According to the general geological conditions of the mining coal face in shallow coal seam, $\theta$ is set to be $0 \sim 12^{\circ}$. Calculated by formula (11), under different values of $n$, if broken rocks of loading key strata do not appear downward sliding movement, the conditions which should be satisfied are shown in Figure 11(a). It is shown that it must meet the following condition: $\varepsilon>2.0$ if the downward sliding movement of "step beam" structure does not occur. The limit span-thickness ratio $\varepsilon$ of broken rocks of loading key strata in shallow coal mining is generally below $2.0[6,7]$. Therefore the movement form is manifested in downward sliding movement.

The "voussoir beam" structure of loading key strata is shown in Figure 9(b). Rock block $N$ subsides with the compaction of coal gangue in the lower caving zone (caving gangue is irregularly accumulation in goaf). Rock $M$ rotates with the advance of working face and is supported by rock $M$ at point $A$ and rock $\mathrm{N}$ at point $B$.

According to the analysis of key rock $M$ of "step beam" structure in loading key strata, the discriminant of broken rock $M$ in loading key strata when it does not appear downward sliding movement can be analyzed according to $n=1.0$ in formula (11). The condition which should be satisfied if rock M of "step beam" structure in loading key strata does not appear downward sliding movement is

$$
\varepsilon \geq \frac{2 \tan \theta}{\sin \theta(4-\tan \theta)} .
$$

Whether the downward sliding movement of rock $M$ occurs is related to the span-thickness ratio $\varepsilon$ and the rotation angle $\theta$ of the rock can be seen from the above formula. Figure 11(b) is the condition which should be satisfied if the rock does not appear downward sliding movement.

It can be seen from Figure 11(b) that it must meet the following condition: $\varepsilon>0.5$ if the downward sliding movement of "step beam" structure does not occur. The limit span-thickness ratio of broken block in shallow thick coal seam mining is larger than $0.5[6,7]$. Therefore the movement form is manifested in downward rotation movement.

Due to the effects of the breaking angle $(a)$ of rocks in the caving zone, the fracture of the loading key strata lagged behind the fracture of the coalface by a distance of $l_{T}$. Periodic rupture and movement of loading key strata lead to the periodic generation of surface fissures. Surface mining-induced fissures are step-type fissures and collapsetype fissures when the movement form of breaking loading key strata is manifested in downward rotation movement. The surface horizontal deformation and fissures horizontal opening increase when the movement form of breaking loading key strata is manifested in downward rotation movement. As the physical and mechanical indexes of loess and aeolian sand cover are low, the fissure horizontal opening amount 


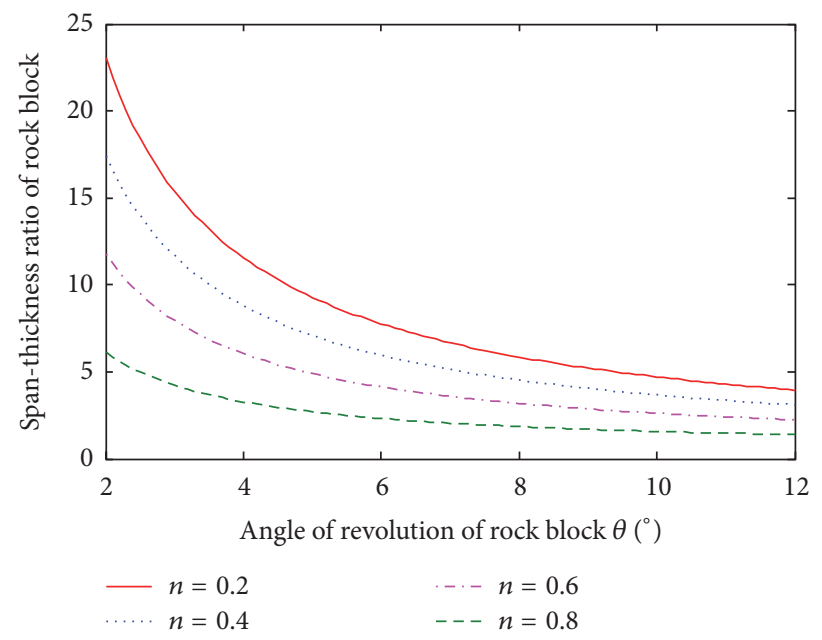

(a)

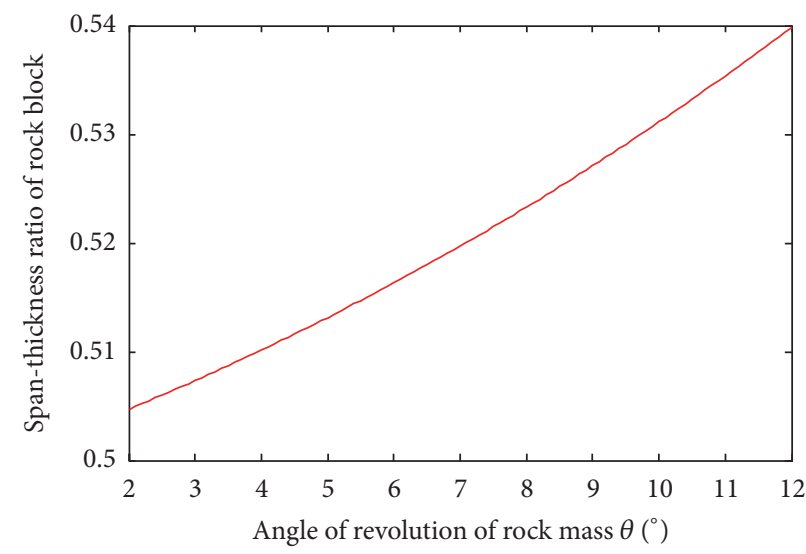

(b)

FIGURE 11: Generating condition of rock downward rotation movement.

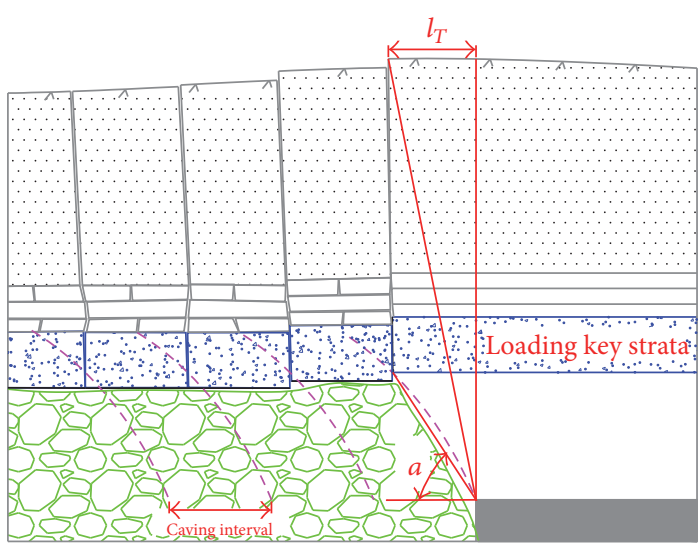

(a)

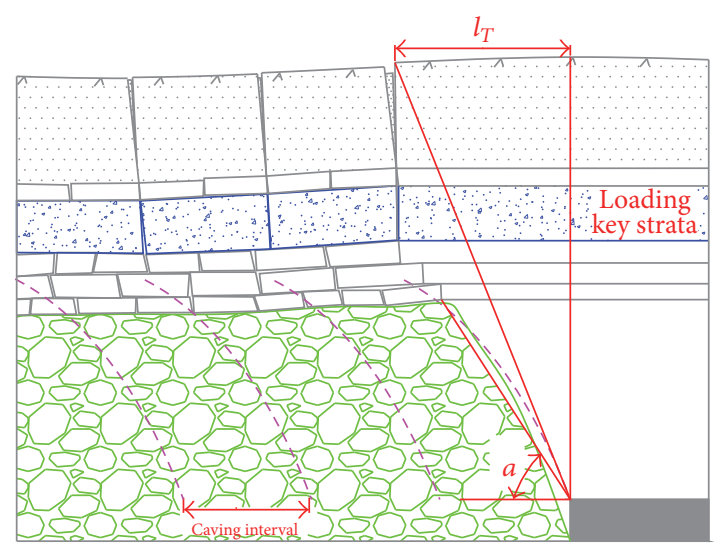

(b)

FIGURE 12: Periodic movement of loading key strata and formation of surface fissures.

increases with the movement of the loading key strata. The periodic movement of loading key strata and the formation process of surface fissures are shown in Figure 12.

It can be seen from Figure 12 that the vertical throw $\Delta w$ of surface fissures is mainly determined by the subsidence amount $w$ of broken rocks of loading key strata. The horizontal opening $\Delta u$ of surface fissures is mainly determined by revolution angle $\theta . \Delta w$ and $\Delta u$ have positive correlation relationship with $\theta$. Controlling and reducing the vertical subsidence amount $w$ and revolution angle $\theta$ of loading key strata broke rocks to reduce the generation of damaging surface fissures.

\section{Analysis of Mining Technology to Reduce the Generation of Damaging Surface Fissures in Shallow Coal Seam Mining}

On the basis of above researches, mining technologies for controlling the formation of damaging surface fissures have been proposed by reducing the subsidence amount $w$ and the revolution angle $\theta$ of broken rocks. The control effect is analyzed by 3DEC numerical simulation based on the geological conditions of Working face 4104 and Working face 6104 .

5.1. Mining with Narrow Coal Pillar and Limited Thickness Extraction to Control the Surface Fissures in the Surrounding Area of Goaf. The ground surface of the shallow coal seam mining face will generate mining-induced fissures [24]. Due to the existence of entry protection coal pillar, two adjacent working faces near the coal pillar generate permanent surface fissures (see Figure 13). The ground surface near the beginning line and the terminal line of working face will also generate permanent surface fissures (see Figure 14). These surface fissures generally connect ground surface with goaf, which have great influence on safety mining and surface ecological environment of mining area. 


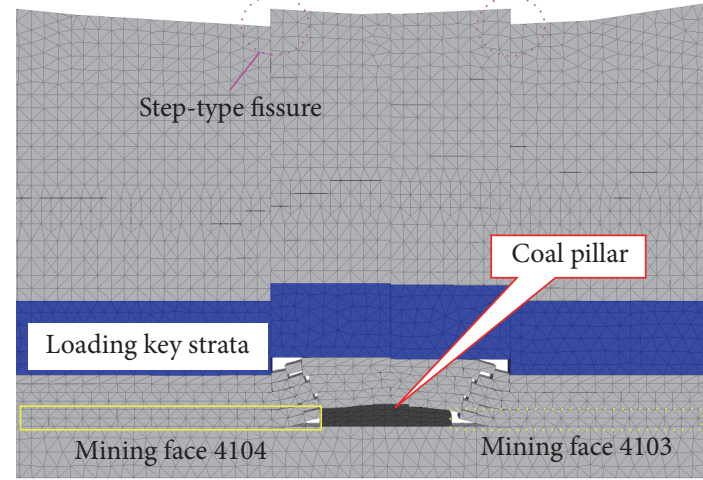

(a) Coal pillar mining

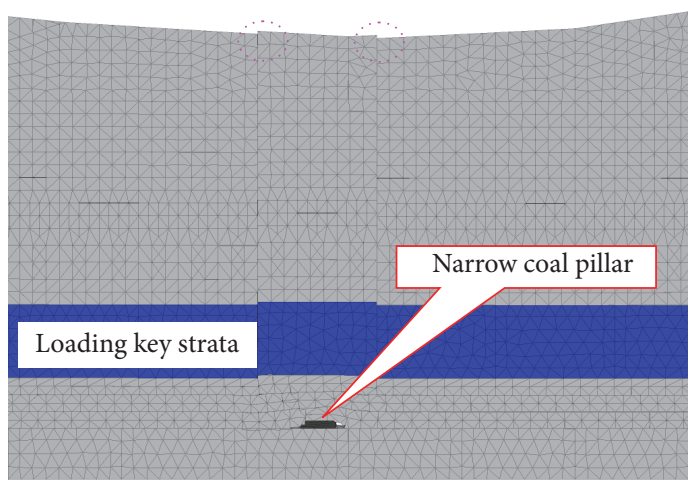

(b) Mining with narrow coal pillar

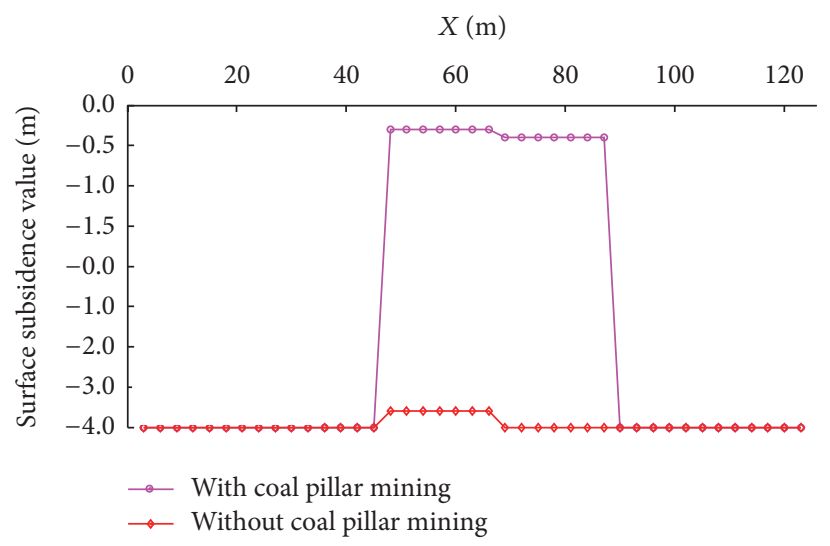

(c) Surface subsidence value

FIGURE 13: Morphological development of ground fissures under conditions of coal pillar mining and mining with narrow and small coal pillar.

In order to control the damaging surface fissures on chain pillar side of mining face roadway, mining with narrow coal pillar is proposed [25]. Based on the production and geological conditions of Working face 4104, the morphological development of mining-induced fissures under the condition of coal pillar mining and mining with narrow coal pillar are analyzed. The results are shown in Figure 13.

It can be seen that loading key strata above coal pillar lack support under the condition of mining with narrow coal pillar. They will rotate and sink with the advancing of working face and tend to be stable. There are no obvious surface steptype fissures. The main benefit of mining with narrow coal pillar is to avoid or reduce obvious surface fissures and reduce uneven surface subsidence.

In order to control the damaging ground fissures near the beginning line and the terminal line of working face, limited thickness extraction for the gradual increase (decrease) of mining height is put forward. Based on the production and geological conditions of Working face 6104, taking the mining area near the beginning line as an example, the morphological development of surface fissures under conditions of normal mining and limited thickness extraction are compared and analyzed. The results are shown in Figure 14.
It can be seen that vertical throw of surface mininginduced fissures near the beginning line reaches $3.8 \mathrm{~m}$ and connects ground surface with goaf under the condition of normal mining, which will cause serious damage to the surface ecological environment. The sinking amount of the loading key strata sinks in stages with the increasing of mining height, and the subsidence amount of each stage is smaller than it under the normal mining condition. When using the mining technology of gradual increasing mining height (limited thickness extraction) near the beginning line, there are two or more surface fissures. The vertical throw of each fissure is obviously reduced. And its maximum value is $1.7 \mathrm{~m}$, which is significantly reduced compared with it under the normal mining conditions.

5.2. Backfill Mining and Rapid Advancing Mining to Control the Surface Fissures in Mining Process. In the mining process of shallow coal seam, surface fissures will be generated and developed dynamically with the advancing of work face. Their development dimension parameter shows a dynamic change characteristic with movement of the loading key strata. Due to the crushing and expanding 

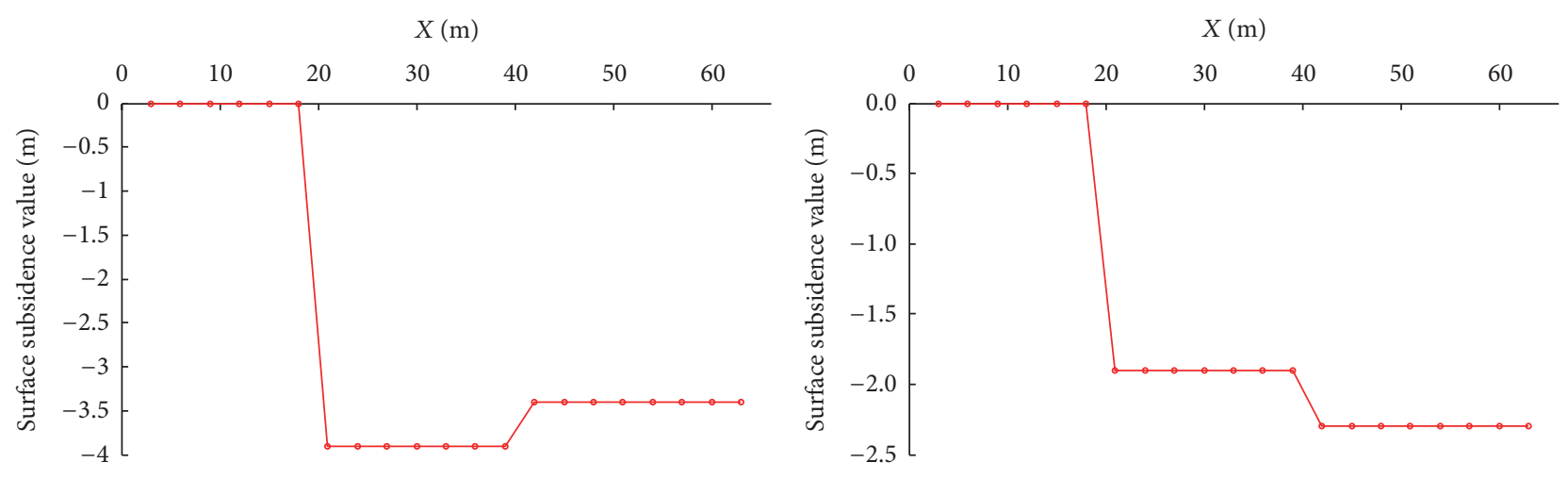

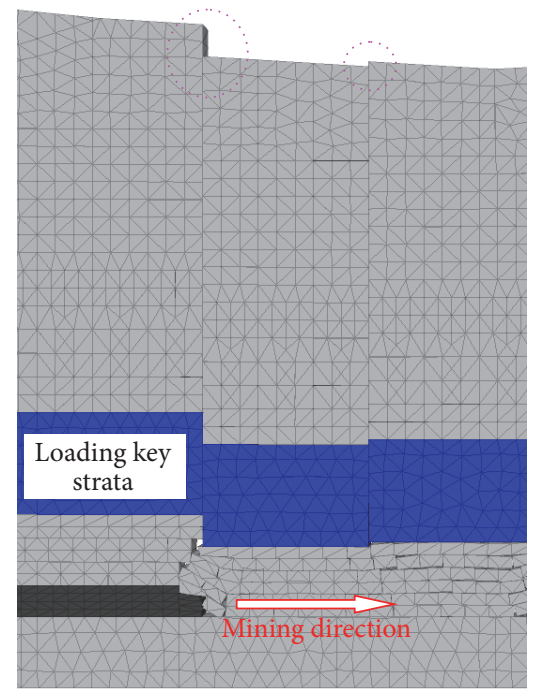

(a) Normal mining

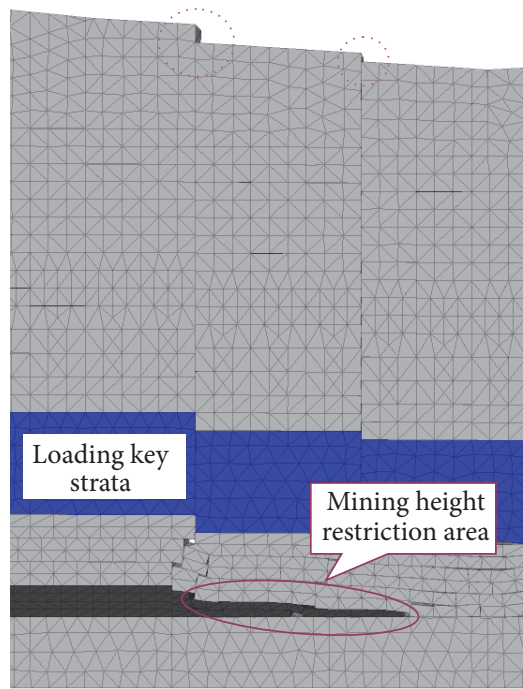

(b) Limited thickness extraction

FIGURE 14: The influence of limited mining height on the morphological development of mining-induced fissures near the beginning line in shallow coal seam mining.

extrusion of surface soil, they do not tend to be closed with the broken rocks movement of the loading key strata but keep a certain value of vertical throw and horizontal opening. In order to control the surface damaging fissures generated periodically, the rotary and sinking amount of adjacent broken rocks in the loading key strata should be controlled.

Backfill mining is to fill the filling materials into goaf of working face in order to control overburden strata caving and surface subsidence in goaf $[26,27]$. In order to control surface fissures of shallow coal seam, the authors take gangue filling as an example to analyze the control effect of backfill mining in Working face 4104 on the morphological development of surface mining-induced fissures. The results are shown in Figure 15.

It can be seen that the rotary and sinking amount of the loading key strata and the vertical throw of surface fissures are significantly reduced. The influence of surface mining-induced fissures on ecological environment is weakened under the condition of backfill mining.
The movement of overlying strata in shallow coal seam mining has the features of temporal and spatial variation. The rotary and sinking amount of broken rocks of loading key strata gradually increase to maximum value with the advancing of working face. Increasing the advancing speed of working face can slow down the sinking value of loading key strata in goaf within a certain range behind the working face and then reduce the development size of surface mining-induced fissures and reduce its damage to the surface ecological environment. Figure 16 shows the morphological development of surface mining-induced fissures at different advancing speed in Working face 4104. In the mining process, different time-steps calculating DEC numerical calculation software represent different mining speeds (3000 timesteps represent slow advance, 2000 time-steps represent medium speed advance, and 1000 time-steps represent rapid advance).

It can be seen that the maximum vertical throw of the surface fissures is $1.6 \mathrm{~m}$ under the condition of slow 


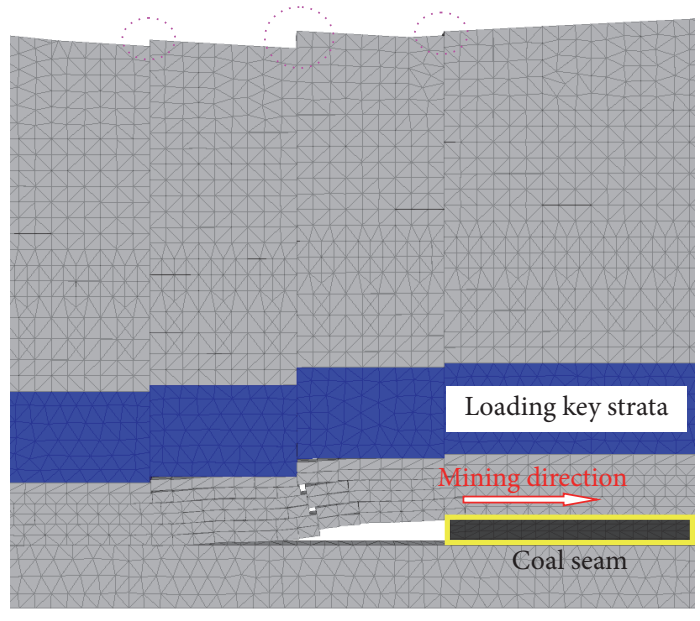

(a) Normal mining

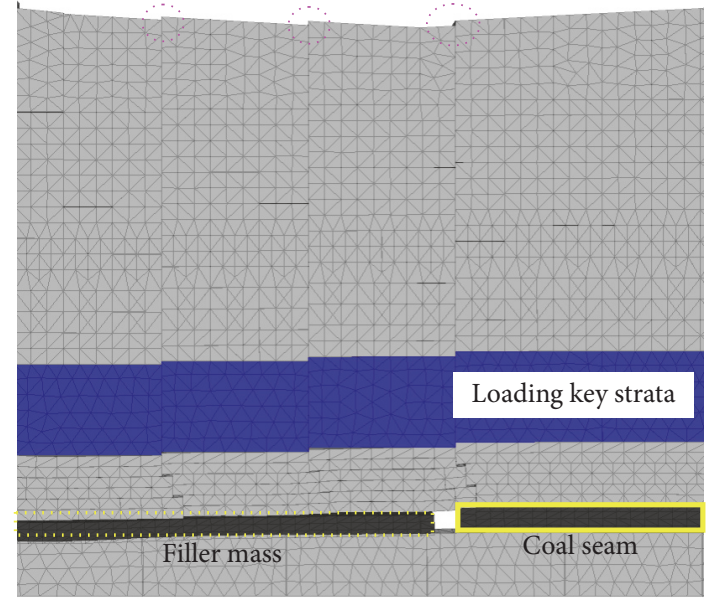

(b) Backfill mining

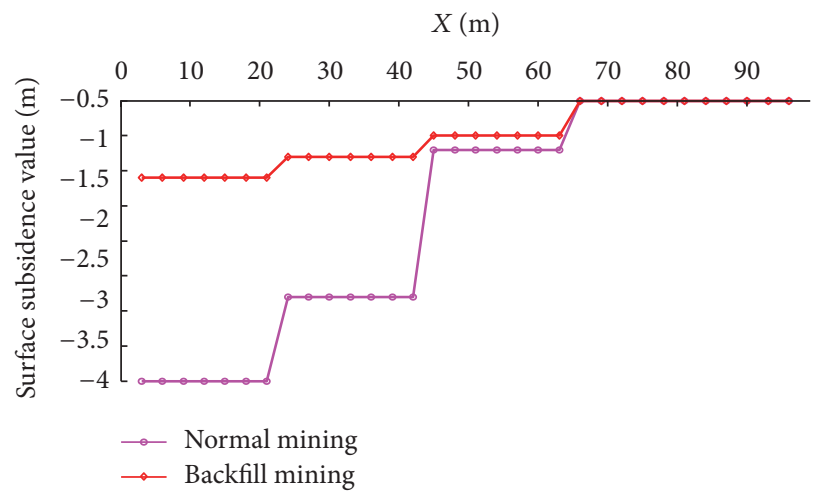

(c) Surface subsidence value

FIGURE 15: Control effect of backfill mining on morphological development of surface mining-induced fissures.

advancing. The maximum vertical throw of the surface fissures is $0.7 \mathrm{~m}$ under the condition of medium-speed advancing. The maximum vertical throw of the surface fissures is $0.4 \mathrm{~m}$ under the condition of fast advancing. The vertical deformation amount of adjacent broken rocks of the loading key strata and the vertical throw of surface mining-induced fissures are larger under the condition of slow advancing. Along with the acceleration of the advancing speed, the broken rocks of loading strata show the characteristics of slow sinking and the vertical throw of surface fissures is reducing.

\section{Conclusions}

(1) Two typical mining-induced fissures, step-type fissures and collapse-type fissures, can be generated on the ground surface of shallow coal seam mining. The fissures with large vertical throw or horizontal opening can severely impact on water resources protection and surface ecological environment of mining area.

(2) The surface fissures are generated periodically with the advancing of working face and distributed along the length direction of the working face. The development dimension of the fissures is changed dynamically with the roof weighting and movement of overlying strata.

(3) The fracture of loading key strata causes the movement of overlying strata and covering layer, which leads directly to surface mining-induced fissures and influences their morphological development. The rotary and sinking amount of broken rock determines the development size of surface fissures.

(4) In order to control the damaging surface fissures in shallow coal seam mining, the mining technologies to reduce damaging ground fissures are put forward, including mining with narrow coal pillar, limited thickness extraction, backfill mining, and rapid advancing mining. 


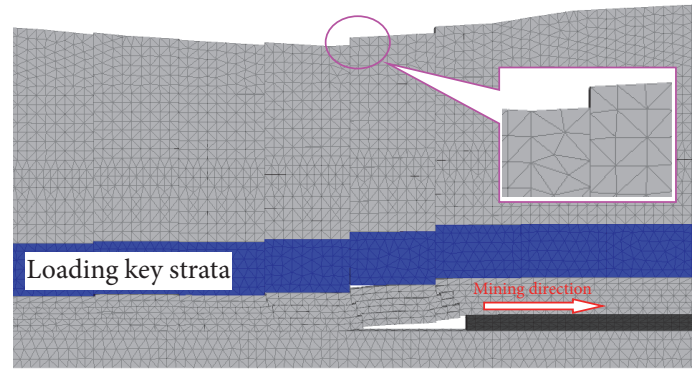

(a) Slow advance

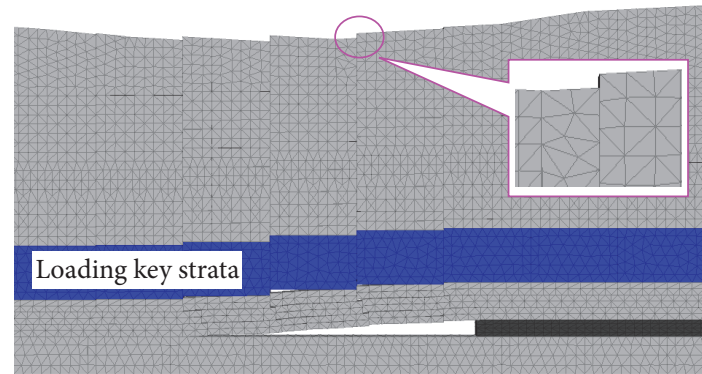

(b) Medium-speed advance

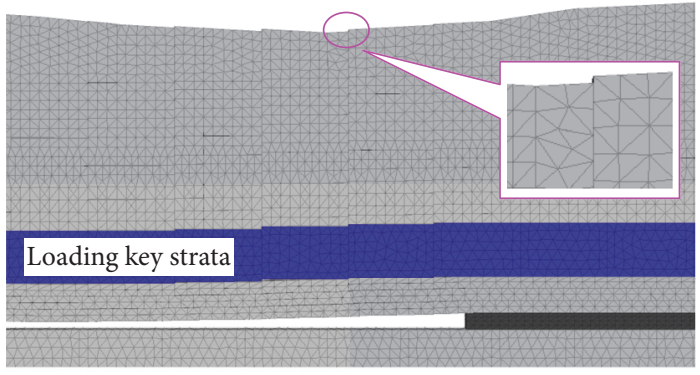

(c) Rapid advance

FIGURE 16: The influence of mining coal face advancing speed on the morphological development of surface mining-induced fissures.

\section{Conflicts of Interest}

The authors declare that they have no conflicts of interest.

\section{Acknowledgments}

The research work of this paper is supported by the "National Natural Science Foundation of China (51574220)" and "the Fundamental Research Funds for the Central Universities of China University of Mining and Technology (2014ZDPY21).” This support is gratefully acknowledged.

\section{References}

[1] W. B. Zhu, J. L. Xu, X. Kong, D. Y. Xuan, and W. Qin, "Study on pillar stability of wongawilli mining area in shallow close distance coal seams," in Proceedings of the 6th International Conference on Mining Science and Technology, ICMST '09, pp. 235-242, China, October 2009.

[2] K. G. Fan, G. L. Liu, T. Q. Xiao, and L. Zheng, "Study on overlying strata movement and structure features aroused by mountainous shallow buried coal seam mining," in Proceedings of the 2nd International Conference on Mine Hazards Prevention and Control, pp. 76-82, Atlantis Press, Paris, France, October 2010.

[3] G. B. Stracher and T. P. Taylor, "Coal fires burning out of control around the world: thermodynamic recipe for environmental catastrophe," in Proceedings of the Symposium on Coal Fires Burning Around the World, vol. 59, pp. 7-17, Elsevier science BV, Denver, Colorado, February 2003.

[4] F. G. Bell, T. R. Stacey, and D. D. Genske, "Mining subsidence and its effect in the environment: some differing examples," Environmental Geology, vol. 40, no. 1-2, pp. 135-152, 2000.
[5] X. Querol, X. Zhuang, O. Font et al., "Influence of soil cover on reducing the environmental impact of spontaneous coal combustion in coal waste gobs: a review and new experimental data," International Journal of Coal Geology, vol. 85, no. 1, pp. 2-22, 2011.

[6] Q. X. Huang, M. G. Qian, and P. W. Shi, "Structural analysis of main roof stability during periodic weighting in longwall face," Journal of China Coal Society, vol. 24, no. 6, pp. 581-585, 1999 (Chinese).

[7] Q.X. Huang, "Ground pressure behavior and definition of shallow seams," Chinese Journal of Rock Mechanics and Engineering, vol. 21, no. 8, pp. 1174-1177, 2002 (Chinese).

[8] P. W. Xing, X. M. Song, and Y. P. Fu, "Study on similar simulation of the roof strata movement laws of the large mining height workface in shallow coal seam," in Proceedings of the 2nd International Conference on Structures and Building Materials (ICSBM '12), vol. 450-451, pp. 1318-1322, Trans Tech Publications LTD., Hangzhou, China, March 2012.

[9] J. L. Xu, W. B. Zhu, X. Z. Wang, and M. S. Yi, "Classification of key strata structure of overlying strata in shallow coal seam," Journal of China Coal Society, vol. 34, no. 7, pp. 865-870, 2009 (Chinese).

[10] G. W. Fan, D. S. Zhang, and L. Zhou, "Fracture zonation for overlying strata in underground mining of shallow coal seam," in Proceedings of the 3rd International Symp on Multi-field Coupling Theory of Rock and Soil Media and its Applications, vol. 594-597, pp. 235-242, Trans Tech Publications LTD., Yichang, China, October 2012.

[11] C. J. Booth and E. D. Spande, "Potentiometric and aquifer property changes above subsiding longwall mine panels, illinois basin coalfield," Groundwater, vol. 30, no. 3, pp. 362-368, 1992.

[12] C. J. Booth, A. M. Curtiss, P. J. Demaris, and R. A. Bauer, "SiteSpecific variation in the potentiometric response to subsidence 
above active longwall mining," Environmental and Engineering Geoscience, vol. 6, no. 4, pp. 383-394, 2000.

[13] A. H. M. Ng, H. C. Chang, L. Ge, C. Rizos, and M. Omura, "Assessment of radar interferometry performance for ground subsidence monitoring due to underground mining," Earth, Planets and Space, vol. 61, no. 6, pp. 733-745, 2009.

[14] M. Marschalko, M. Bednárik, I. Yilmaz, T. Bouchal, and K. Kubečka, "Evaluation of subsidence due to underground coal mining: an example from the Czech Republic," Bulletin of Engineering Geology and the Environment, vol. 71, no. 1, pp. 105111, 2012.

[15] C. J. Booth and L. P. Bertsch, "Groundwater geochemistry in shallow aquifers above longwall mines in Illinois, Ill, USA," Hydrogeology Journal, vol. 7, no. 6, pp. 561-575, 1999.

[16] L. Q. Ma, X. Du, F. Wang, and J. M. Liang, "Water-preserved mining technology for shallow buried coal seam in ecologicallyvulnerable coal field: a case study in the shendong coal field of China," Disaster Advances, vol. 6, no. 5, pp. 268-278, 2013.

[17] D. Zhang, G. Fan, and X. Wang, "Characteristics and stability of slope movement response to underground mining of shallow coal seams away from gullies," International Journal of Mining Science and Technology, vol. 22, no. 1, pp. 47-50, 2012.

[18] M. P. Singh and R. R. Shukla, "Petrographic characteristics and depositional conditions of Permian coals of Pench, Kanhan, and Tawa Valley Coalfields of Satpura Basin, Madhya Pradesh, India," International Journal of Coal Geology, vol. 59, no. 3-4, pp. 209-243, 2004.

[19] K. D. Kim, S. Lee, H. J. Oh, J. K. Choi, and J.-S. Won, "Assessment of ground subsidence hazard near an abandoned underground coal mine using GIS," Environmental Geology, vol. 50, no. 8, pp. 1183-1191, 2006.

[20] M. G. Qian and P. W. Shi, Coal Mine Ground Pressure and Control, China University of Mining and Technology Press, Xuzhou, China, 2003, (Chinese).

[21] H. L. Kong, Z. Q. Chen, W. K. Bu, B. Wang, and L. Z. Wang, "A primary exploration on the relationships among loading key strata, water-resisting key strata and seepage key strata," Journal of the China Coal Society, vol. 33, no. 5, pp. 485-488, 2008 (Chinese).

[22] S. J. Ma and J. S. Cao, "Numerical simulation and analysis of the height of overlying strata fracture belt based on UDEC," in Proceedings of the 3rd International Conference on Civil, Architectural and Hydraulic Engineering (ICCAHE '14), pp. 512516, Trans Tech Publications LTD., Hangzhou, China, March 2014.

[23] G. Saeedi, K. Shahriar, and B. Rezai, "Estimating volume of roof fall in the face of longwall mining by using numerical methods," Archives of Mining Sciences, vol. 58, no. 3, pp. 767-778, 2013.

[24] B. C. Zhao, X. Y. Yu, G. Y. Huang, and G. L. Zhao, "Effect analysis on destroy form about overburden by RRL and RRM on the condition of shallow coal seam," in Proceedings of the 7th International Symposium on Safety Science and Technology (ISSST '10), pp. 1576-1580, Science Press Beijing, Beijing, China, October 2010.

[25] W. Li, J. Bai, S. S. Peng, X. Wang, and Y. Xu, "Numerical modeling for yield pillar design: a case study," Rock Mechanics and Rock Engineering, vol. 48, no. 1, pp. 305-318, 2013.

[26] X. Feng, N. Zhang, L. Gong, F. Xue, and X. Zheng, "Application of a backfilling method in coal mining to realise an ecologically sensitive 'black gold' industry," Energies, vol. 8, no. 5, pp. 36283639, 2015.
[27] J. Zhang, Q. Zhang, Q. Sun, R. Gao, D. Germain, and S. Abro, "Surface subsidence control theory and application to backfill coal mining technology," Environmental Earth Sciences, vol. 74, no. 2, pp. 1439-1448, 2015. 


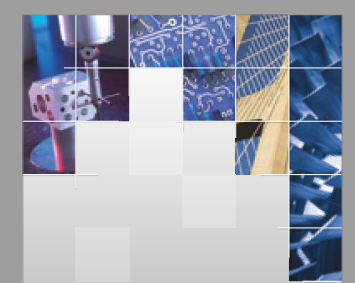

\section{Enfincering}
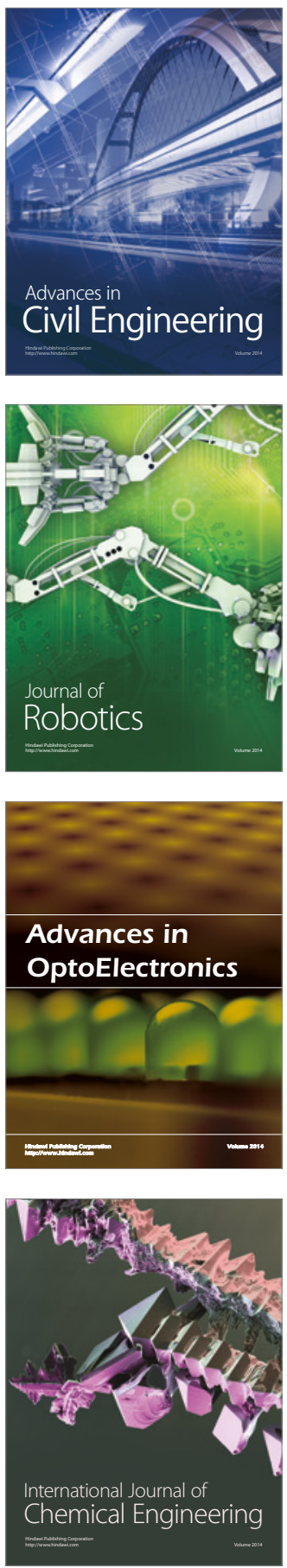

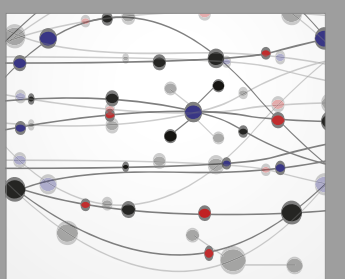

The Scientific World Journal

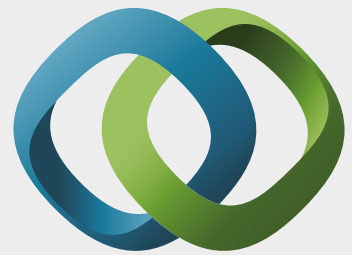

\section{Hindawi}

Submit your manuscripts at

https://www.hindawi.com
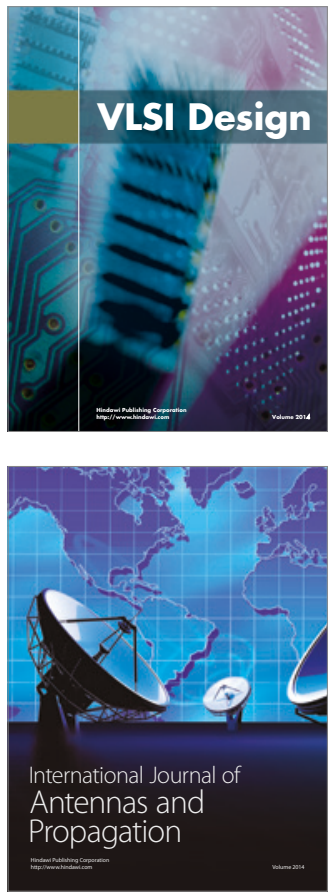

\section{Rotating}

Machinery
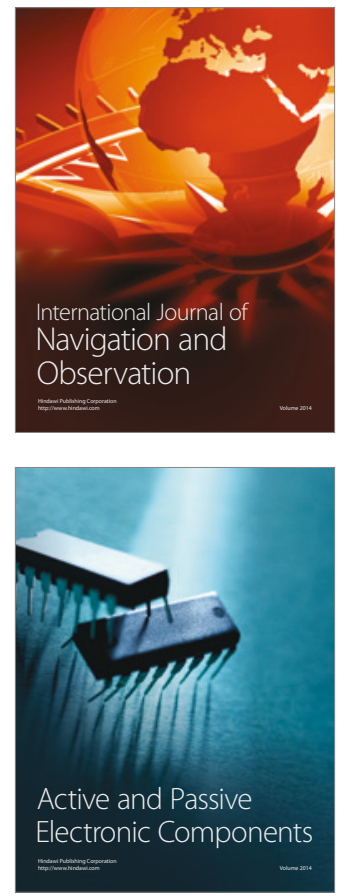
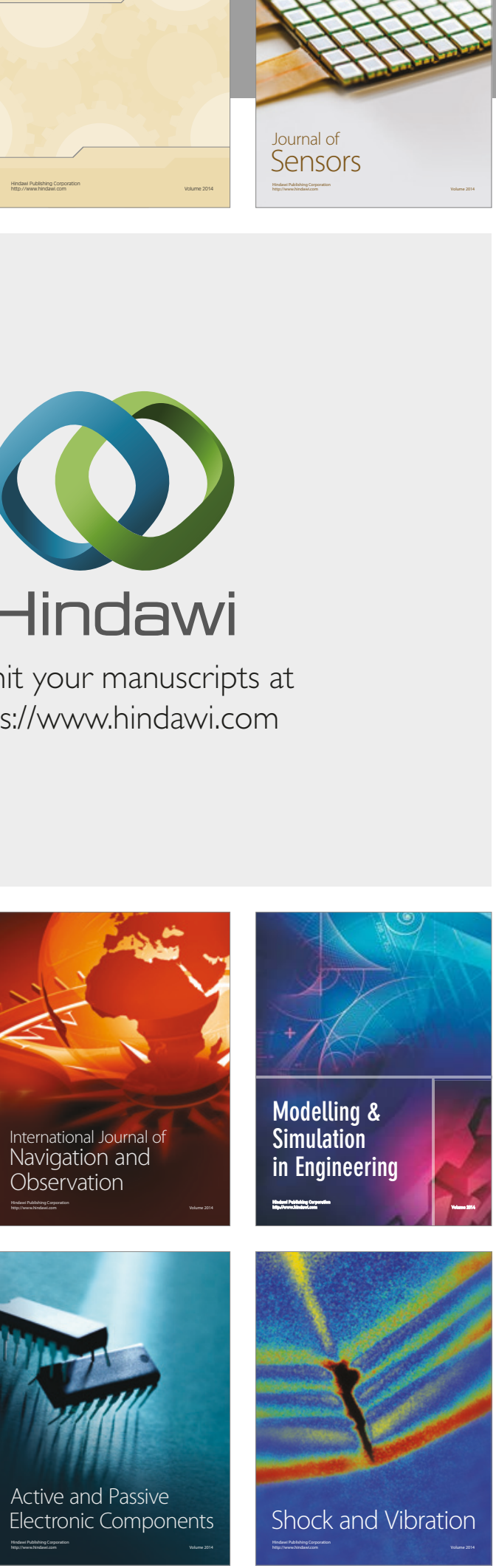
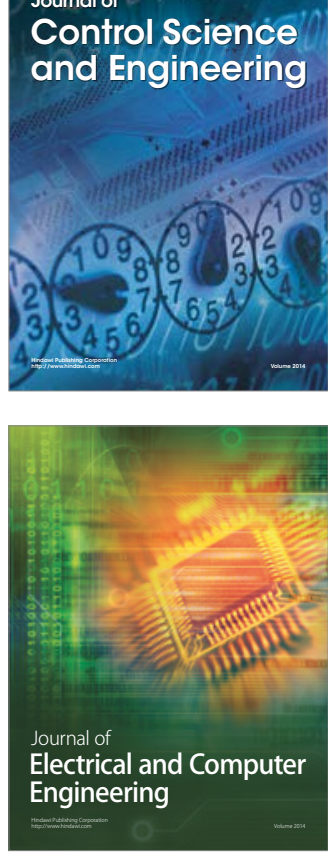

Distributed

Journal of

Control Science

and Engineering
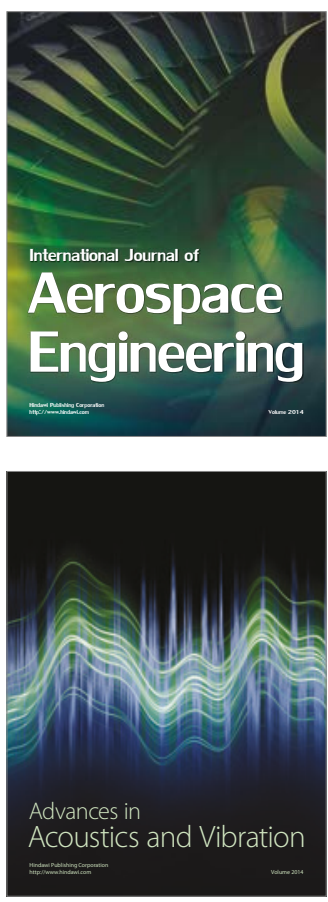

Sensor Networks 